\title{
Seasonal dynamics of Daphnia laevis Birge, 1878 ephippia in a tropical lake with a description of a new methodology for in situ evaluation
}

\author{
Brandão, LPM. ${ }^{a *}$, Pujoni, DGF. ${ }^{a}$ and Maia-Barbosa, PM. ${ }^{a}$ \\ Laboratory of Zooplankton Ecology, Federal University of Minas Gerais - UFMG, Av. Antônio Carlos, 6627, \\ Pampulha, CP 486, CEP 31270-901, Belo Horizonte, MG, Brazil \\ *e-mail: lucianapmb@hotmail.com
}

Received: March 11, 2013 - Accepted: May 9, 2013 - Distributed: August 31, 2014

(With 6 figures)

\begin{abstract}
The effect of dormancy in zooplankton populations is still unknown, largely because of the lack of methods to estimate hatching and production of the dormant stages. This study aimed to compare the production and hatching rates of ephippia of Daphnia laevis between thermal stratification and mixing periods in Jacaré Lake (Middle Rio Doce, Minas Gerais, Brazil). For this, we collected ephippia on the sediment with core sampler and we created a device called the "Ephippial Collector". There was a significant difference in ephippia hatching in situ between stratification and mixing periods (Pearson's Chi-squared test $\mathrm{p}<0.001$ ), being higher in the second one. Significant differences in the hatching rates between periods was observed in the laboratory only for ephippia collected with Ephippial Collectors (Pearson's Chi-squared test $\mathrm{p}<0.001)$, being higher during the mixing period $(\sim 8 \%)$. The core sample allows the collection of a certain fraction of the sediment that may contain a mixture of ephippia produced in different periods, i.e., may contain old and not viable ephippia, which masks the hatching rate. Thus, seasonality in hatching rates of ephippia was reported only by Ephippial Collectors. The higher hatching rate observed during the mixing period in the lake suggests that individuals hatched from ephippia may contribute to the increase in the population of $D$. laevis in the water column at this time.
\end{abstract}

Keywords: ephippium, ephippial collector, in situ, resting eggs, zooplankton.

\section{Dinâmica sazonal de efípios de Daphnia laevis Birge 1878 em um lago tropical com a descrição de uma nova metodologia para avaliação in situ}

\begin{abstract}
Resumo
O efeito de dormência nas populações zooplanctônicas é ainda desconhecido, em grande parte devido à falta de metodologias para estimar a produção e eclosão de formas dormentes. Esse trabalho teve como objetivo comparar as taxas de produção e eclosão de efípios de Daphnia laevis entre períodos de estratificação térmica e de mistura na lagoa Jacaré (Médio Rio Doce, Minas Gerais, Brasil). Para isso, foi coletado efípios no sedimento com amostrador "corer" e foi criado um aparato denominado "Coletor de Efípios". Houve diferença significativa na eclosão de efípios in situ entre período de estratificação térmica e de mistura (Pearson's Chi-squared test $\mathrm{p}<0.001$ ), sendo maior no segundo. Diferenças significativas nas taxas de eclosão em laboratório entre os períodos foram observadas somente para os efípios coletados com os Coletores de Efípios (Pearson's Chi-squared test $\mathrm{p}<0.001$ ), sendo maiores durante período de mistura ( $8 \%)$. O amostrador "corer" permite a coleta de determinada fração do sedimento que pode conter uma mistura de efípios produzidos em períodos distintos, ou seja, pode conter efípios antigos e não mais viáveis, o que mascara a taxa de eclosão. Dessa forma, a sazonalidade nas taxas de eclosão dos efípios foi constatada apenas pelos Coletores de Efípios. A maior taxa de eclosão observada em período de mistura do lago sugere que os indivíduos eclodidos dos efípios podem contribuir para o aumento da população de D. laevis na coluna de água nesta época.
\end{abstract}

Palavras-chave: efípio, coletor de efípios, in situ, ovos de resistência, zooplâncton.

\section{Introduction}

Part of zooplankton communities may be present in the sediment of lakes as dormant stages. The dormant eggs are formed by sexual reproduction and have distinct morphology and biochemistry from those parthenogenetic eggs produced under normal conditions (Hairston Junior, 1996; Pauwels et al. 2007). Within the Anomopoda (Cladocera) order (e.g. Daphnia spp.), these dormant eggs are protected by the carapace of the mother, forming a 
structure called ephippium. In general, the dormant eggs and ephippia are dark with a thick protective membrane and a well developed cytoplasm. They may remain viable for decades or centuries and accumulate in large numbers in the sediment (Hairston Junior, 1996; Cáceres, 1998; Crispim et al. 2003; Cáceres and Tessier, 2004), forming an "egg bank". Some studies have shown that fluctuations in population densities can be correlated to dormant eggs (Mnatsakanova and Polishchuk, 1996; Cáceres, 1998; Hairston Junior et al., 2000). Thus, the importance of the diapause in the zooplankton population dynamics of many species has also been increasingly recognised.

The stimuli to produce and hatch resting eggs seem to be very similar. Among the cited stimuli to produce resting eggs and ephippia, are: fluctuations in temperature (Jersabek and Schabetsberger, 1995), abrupt increases in population density (King and Snell, 1980; Ban, 1992), predation pressure (Slusarczyk, 1995; Pijanowska and Stolpe, 1996), food scarcity (Slobodkin, 1954; Gilbert, 1995), photoperiod and competition (Gilbert and Williamson, 1983), or a combination of these factors (Kleiven et al., 1992). In temperate regions, photoperiod and temperature are recognised as the main factors that stimulate the production and hatching of resting eggs (Wolf and Carvalho, 1989; Hairston Junior et al., 2000; Brendonck and De Meester, 2003; Gyllström and Hansson, 2004; Vandekerkhove et al., 2005). Other cited factors that can also affect the hatching rates are concentration of oxygen (Lutz et al., 1992; Marcus et al., 1997), salinity (Nielsen et al., 2003) and food availability (Irigoien et al., 2002). High levels of food (spring blooms in temperate environment) were seen to promote the emergence of some Cladocera species (Cáceres, 1998, Hairston Junior et al., 2000). The stimulus for hatching can also occur with a combination of factors such as photoperiod and food (Alekseev and Lampert, 2001).

The usual sampling methodologies try to estimate mainly three aspects of the dormant population: its abundance in the sediment, the production rate by the active population and the birth rate (i.e. hatching rate). Sediment samplers such as corer and dredge are used to assess the abundance and species composition of dormant eggs in the sediment. The corer-like sampler enables the collection of specific layers of the sediment, allowing us to compare ephippia stocked in different periods. Epphipial production was directly measured in lake Michigan by Kerfoot et al. (2004) using sediment traps and also by Altermatt and Ebert (2008) in rock pools using petri dishes to collect settling eggs. Hatching rate estimations of dormant eggs are usually made under laboratory conditions. Mnatsakanova and Polishchuk (1996) suggested collecting a certain layer of sediment and then incubating it under laboratory conditions similar to those of the natural environment. However, Cáceres and Tessier (2003) criticized this methodology due to the difficulty in simulating all the environmental characteristics. New methods have been proposed by some authors to measure hatching rates in situ, such as the use of hatching traps (Herzig, 1985; De Stasio 1989, 1990; Wolf and Carvalho, 1989; Cáceres 1998; Hairston Junior et al., 2000). Cáceres (1998) and Hairston Junior et al. (2000) used traps placed at the bottom of the lake so that individuals hatched from epphipia in the sediment would be retained in a closed chamber collected some time later by diving. These studies have evaluated more efficiently the effect of emergence of dormant forms in the population dynamics of the studied species.

In this study we quantified and compared the production and hatching rates of Daphnia laevis ephippia between thermal stratification and mixing periods in a natural tropical lake. A new method for ephippia sampling was described and its efficiency was evaluated.

\section{Material and Methods}

\subsection{Study Area}

Lake Jacaré (area: $1.03 \mathrm{~km}^{2}$, maximum depth: $9.8 \mathrm{~m}$, coordinates: S $19^{\circ} 48^{\prime} 38.8^{\prime}$, W $\left.42^{\circ} 38^{\prime} 55.5^{\prime \prime}\right)$ is located at the middle Rio Doce basin, near Rio Doce State Park (Parque Estadual do Rio Doce), Minas Gerais, Brazil. The region has a mesothermic tropical semi-humid climate with an average temperature of $25^{\circ} \mathrm{C}$ and a marked seasonality: a rainy summer period (from September to April) and a dry winter period (from May to August) (Tundisi, 1997). The lake is surrounded by monocultures of Eucalyptus spp. and houses a fishing club, with a camping area, receiving an unknown load of domestic sewage. It has been monitored by the Program for Long Term Ecological Research (LTER/ UFMG), at first with seasonal sampling (2000 and 2001) and, from 2002 to 2010, with monthly sampling. Over ten years of monitoring, an annual circulation pattern has been observed with thermal stratification in the summer and homogenisation of the whole water column during the winter, which classifies this lake as warm monomitic.

\subsection{Sampling active Daphnia laevis population in the water column}

Zooplaknton samples were collected in a fixed station of the limnetic region at depths defined by the disappearance of a Secchi disk. A volume of 200L of lake water was filtered (Stihl motorised pump, model P835) through $68 \mu \mathrm{m}$ plankton, stained with rose bengal and preserved with a $4 \%$ formaldehyde solution. All the D. laevis individuals in the sample were counted under a stereomicroscope. Samples were collected monthly from October 2007 to July 2008. Sampling frequency was increased in March and April (weekly samples), months where population densities were increasing.

\subsection{Sampling ephippia in the sediment}

Sediment samples for quantitative analyses of resting eggs and laboratory tests were collected (five samples) in the limnetic region with a gravity core type sampler (Kajak) on the same dates of the active $D$. laevis population samplings. Samples were taken bimonthly only between October 2007 and February 2008 due to the low number of active population in the water column. Just the first five centimetres of the sediment was collected, kept in dark pots and refrigerated at $\pm 5^{\circ} \mathrm{C}$, except the one used for laboratory hatching tests, which was processed in five 
days at most. The water temperature profile was measured using a Yellow Spring probe (model YSI 60).

\subsection{Ephippial Collector: description and sampling}

The Ephippial Collectors are similar to a plankton net with a conical polyester net (used for silk screen) with 200 $\mu \mathrm{m}$ and length/mouth diameter ratio $2 / 1$. A plastic ring with an area equal to $0.2 \mathrm{~m}^{2}$ was used to hold the net and at the end a screwed opening cup was fixed with clamps (Figure 1). The Collectors were placed one metre above the bottom of the lake in the limnetic region suspended by a buoy and firmed by an anchor (Figure 2). Two Ephippial Collectors were placed about ten metres away from each other. These collectors remained in the lake for 22 days during the mixing period, when the active population was at its maximum. During the stratified period the collectors remained for 49 days because the active population was at its minimum and the ephippia production is very low, compared with mixing period. The difference in the number of days sampled does not interfere in the Pearson's Chi-squared Test for Count Data as this test evaluates proportions and not absolute values of ephippia collected. In addition, low proportions (as those in the stratified period) has higher variance that can only be reduced if we increase sample size (i.e. number of ephippia collected).

\subsection{Quantification of eggs in the sediment and laboratory hatching tests}

For quantification of ephippia, sediment samples were taken out from refrigeration, mixed with sucrose solution (1:1) and centrifuged at $3600 \mathrm{rpm}$ for 5 minutes (Onbé,1978,

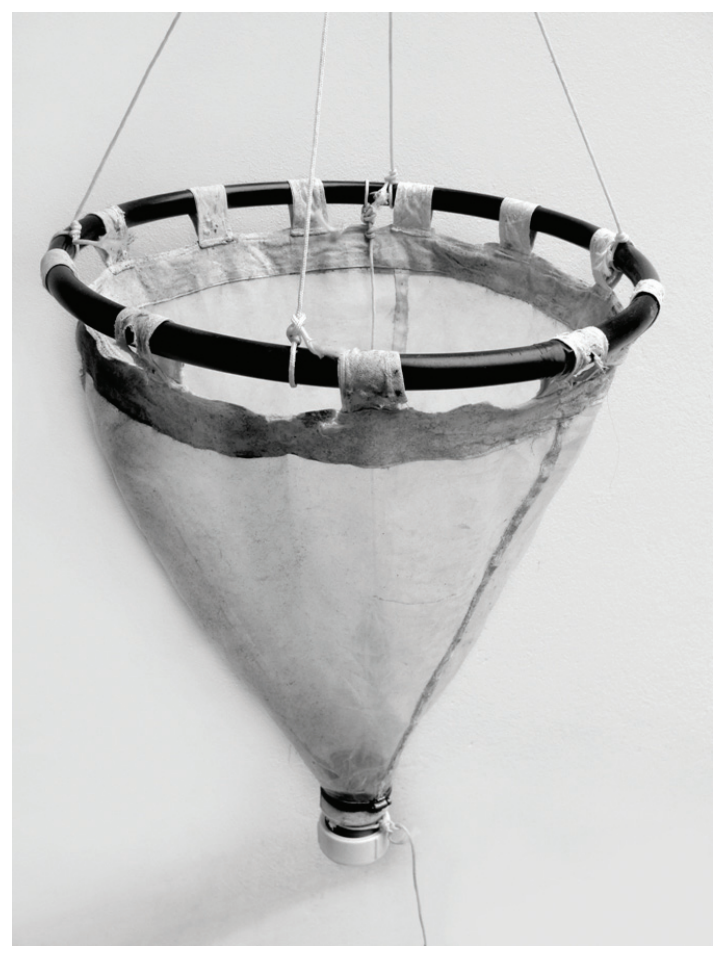

Figure 1. The Ephippial Collector.
Marcus, 1990). The ephippia in the supernatant were rinsed with distilled water and counted under a stereomicroscope (Crispim and Watanabe, 2000). Ephippia used for hatching tests were not centrifuged, but washed under a net until they were free of sediment particles.

The ephippia obtained by the Ephippial Collectors were free of sediment and were directly counted. The following ephippia classification was used: eggs with dark colouration and intact structure, without any kind of damage were considered "normal" (Figure 3); ephippia found longitudinally opened, empty or with only one embryo inside, such as those hatched in laboratory, were classified as hatched in situ; and the yellow coloured eggs, even if closed, were considered "spoiled". Hatching tests were also carried out with these spoiled ephippia.

Hatching experiments were conducted by placing a known number of ephippia in a $50 \mathrm{ml}$ plastic beaker containing about $20 \mathrm{ml}$ of filtered lake water and incubated under the same temperature recorded at the bottom of the lake $\left(23.8^{\circ} \mathrm{C} \pm 1{ }^{\circ} \mathrm{C}\right.$ for mixing period and $26.5 \pm 1{ }^{\circ} \mathrm{C}$ for stratified period) with a 12 hour photoperiod. Eggs were examined every day for hatching success during 45 days.

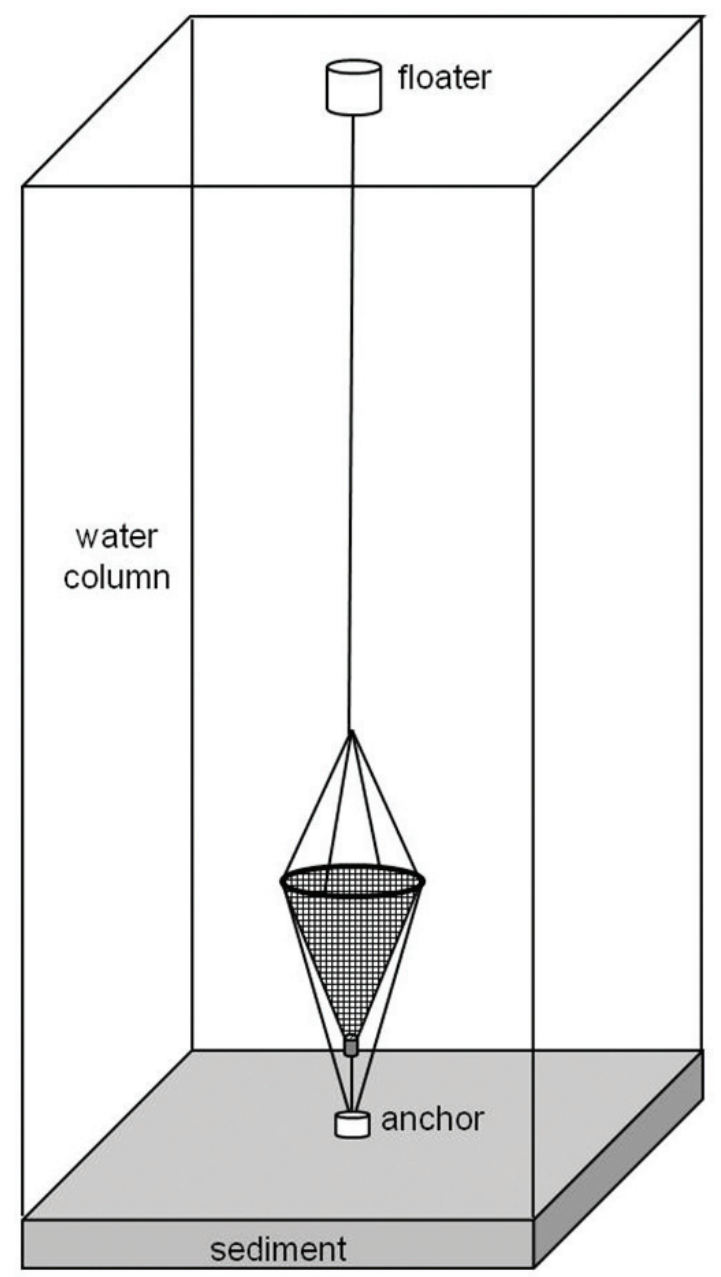

Figure 2. Ephippial Collector placed in lake. 
All born individuals and hatched ephippia were counted and removed and the water renewed.

\subsection{Statistical methods}

In order to verify the effect of the period (stratified/ mixing) on hatching and production rates with Ephippial Collectors, contingency tables were built and a test for homogeneity was performed using the Pearson's Chisquared Test for Count Data, with p-values estimated by the Monte Carlo technique. The statistical analysis and graphics were carried out using R software (R Development Core Team, 2010).

\section{Results}

The lake followed the thermal stratification pattern observed during the previous years of monitoring, remaining stratified from October 2007 to April 2008 and mixing from May 2008 to July 2008 (Figura 4). The active D. laevis population remained in low number from October 2007 to December 2008. From February 2008 to May 2008 a pronounced increase was observed. This pattern was followed by the number of ephippia counted in the sediment core samples (Figure 5).

The active population of $D$. laevis in the water column ranged from 0 to 6076 org. $\mathrm{m}^{-3}$, following the seasonal

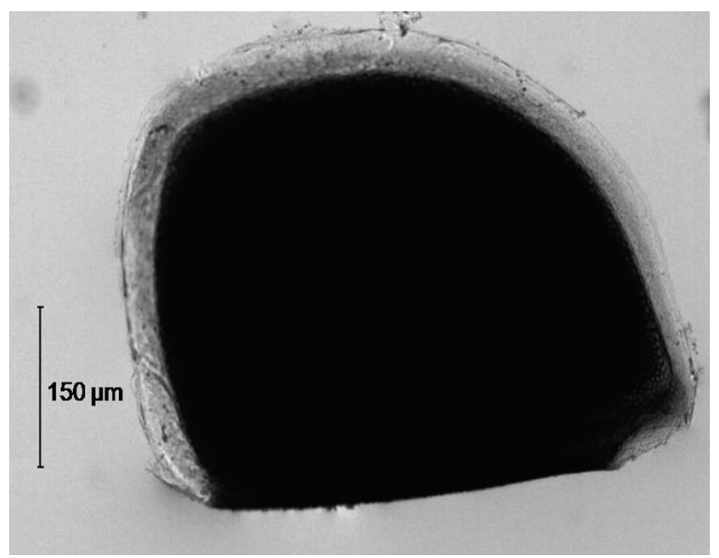

Figure 3. Daphnia laevis ephippium considered normal. pattern already described for this population with higher densities in the mixing period (Figure 5) (Brandão et al., 2012). According to the number of ephippia (sum of two Collectors) produced and hatched in each period and its respective classification, a significant difference was observed between the stratified and mixing periods (Pearson's Chi-squared test $\mathrm{p}<0.001$ ), with higher hatching rates in the second one (i.e. higher proportions of ephippia classified as hatched in situ). During the mixing period, the average daily $D$. laevis ephippia production, collected with the new apparatus, was $204 . \mathrm{m}^{-2}$. day $^{-1}(49.7 \%$ of the eggs classified as hatched in situ) compared with $29 . \mathrm{m}^{-2}$. day $^{-1}(1.3 \%$ of them classified as hatched in situ) during the stratified period (Table 1). Significant difference in hatching rate in the laboratory was observed only for the ephippia collected with Ephippial Collectors (Pearson's Chi-squared test $\mathrm{p}<0.001)$, with higher rates in the mixing period ( $\sim 8 \%$ ) (Figure 6$)$.

\section{Discussion}

As environmental characteristics during the production of ephippia may influence its timing of dormancy (Marcus et al., 1997, Cáceres and Tessier, 2003, Cáceres et al., 2007), it is expected that the hatching rates be different between seasonal periods. This hypothesis was confirmed only with ephippia collected with Ephippial Collectors. The lack of statistical significance in the hatching rates with epphipia collected by corer is evidence that sediment can accumulate eggs produced in different periods, as the hatching rates are a mixture of the two periods. Besides that, hatching rates obtained under laboratory conditions may not represent the field situation (Cáceres and Schwalbach, 2001). They may be overestimated due to higher and constant light and lack of natural chemical inhibitors (Cáceres and Tessier, 2003) or underestimated, as a result of stable conditions, whereas the stimulus involves environmental disturbances (Panarelli et al., 2008). This could explain the low laboratory hatching rates obtained in this study (maximum 8\%, with ephippia collected with Ephippial Collectors) when compared with in situ hatching rates (maximum 58\%) for the mixing period.

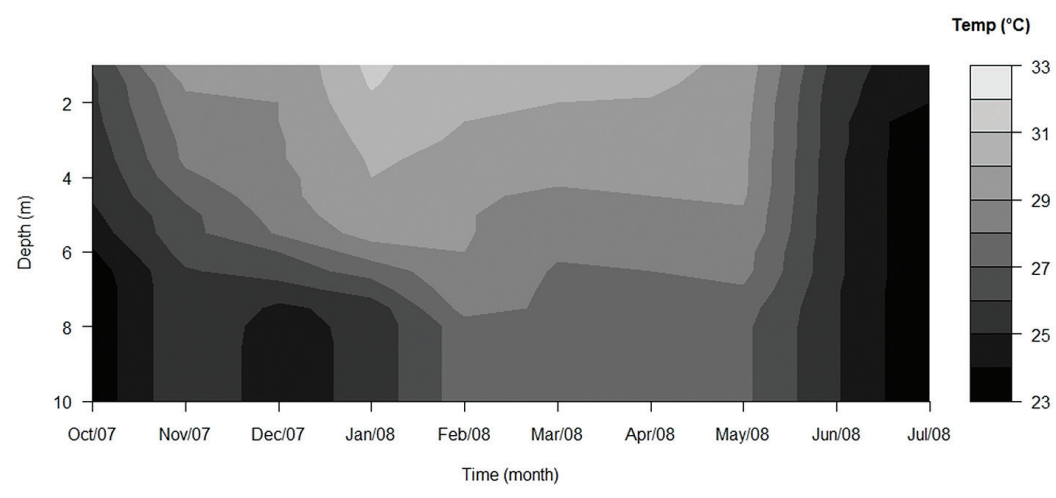

Figure 4. Thermal structure of Jacaré Lake (from October 2007 to July 2008). 


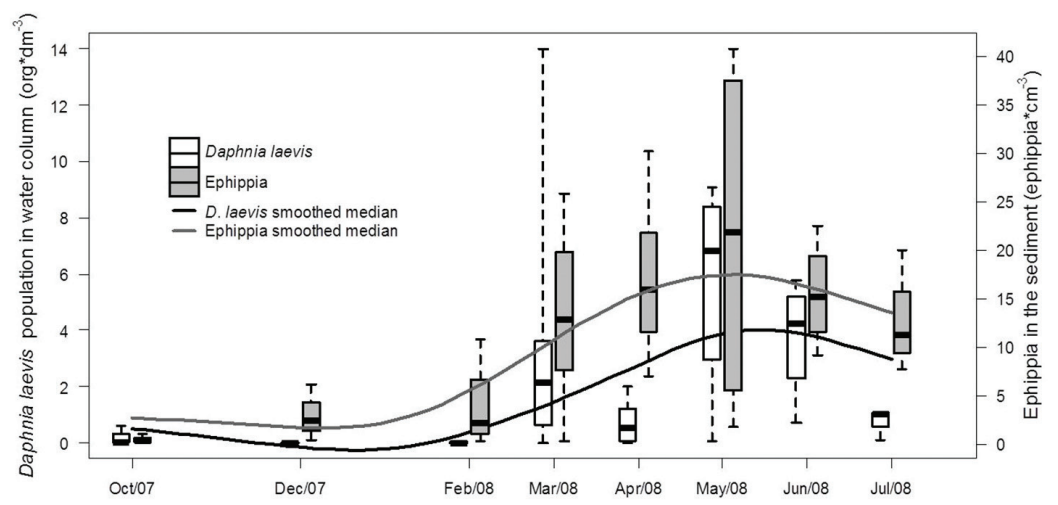

Figure 5. Box plot (minimum, lower quartile (Q1), median, upper quartile (Q3) and maximum) of Daphnia laevis active population in the water column and ephippia in the sediment recorded during the sampling period. The solid line is a smoothing spline of the medians.

Table 1. Number of ephippia and the classification recorded in situ with the Ephippial Collectors placed in lake Jacaré (MG), in stratified and mixing periods.

\begin{tabular}{|c|c|c|c|c|c|}
\hline & & \multicolumn{2}{|c|}{ Mixing period } & \multicolumn{2}{|c|}{ Stratified period } \\
\hline & & Collector 1 & Collector 2 & Collector 1 & Collector 2 \\
\hline Collector & area $\left(\mathrm{m}^{2}\right)$ & 0.2 & 0.2 & 0.2 & 0.2 \\
\hline \multirow{4}{*}{$\begin{array}{l}\text { Ephippia } \\
\text { numbers }\end{array}$} & Normal & 508 & 358 & 257 & 300 \\
\hline & Hatched in situ & 393 & 491 & 7 & 0 \\
\hline & Spoiled & 44 & 0 & 0 & 0 \\
\hline & TOTAL & 945 & 849 & 264 & 300 \\
\hline \multicolumn{2}{|c|}{$\begin{array}{l}\text { Daily } D \text {. laevis ephippia } \\
\text { production (ephippia. } \mathrm{m}^{-2} \cdot \text { day }^{-1} \text { ) }\end{array}$} & 214.8 & 193.0 & 26.9 & 30.6 \\
\hline \multicolumn{2}{|c|}{$\begin{array}{l}\text { Mean daily D. laevis ephippia } \\
\text { production (ephippia. } \mathrm{m}^{-2} \cdot \text { day }^{-1} \text { ) }\end{array}$} & \multicolumn{2}{|c|}{203.9} & \multicolumn{2}{|c|}{28.8} \\
\hline Hatching & & $41.6 \%$ & $57.8 \%$ & $2.7 \%$ & $0.0 \%$ \\
\hline \multicolumn{2}{|c|}{ Mean hatching rate $(\%)$} & \multicolumn{2}{|c|}{$49.7 \%$} & \multicolumn{2}{|c|}{$1.3 \%$} \\
\hline
\end{tabular}

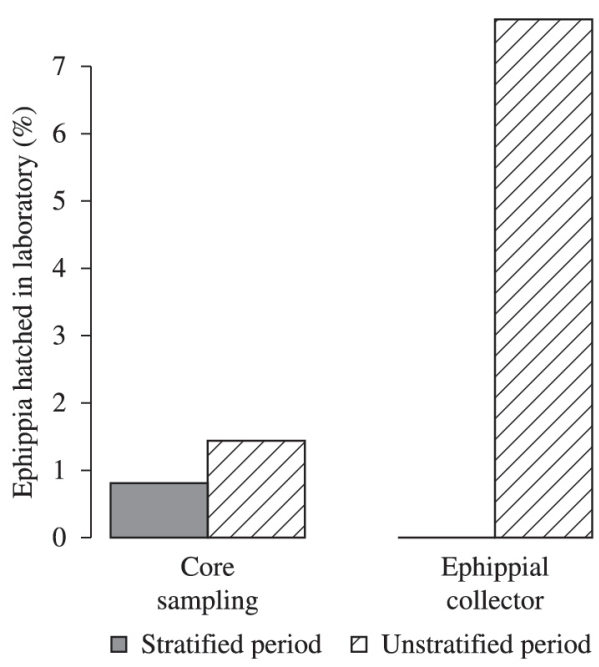

Figure 6. Laboratory ephippia hatching rates with ephippia obtained by corer and by collector in Lake Jacaré (MG) during the stratified and mixing periods from October 2007 to December 2008.
Although few studies have directly estimated hatching rates of ephippia, there is a consensus that just a small fraction of viable embryos break dormancy within a given year (De Stasio 1989, Cáceres 1998; Hairston Junior et al., 2000). However, we observed high hatching rates recorded in the Ephippial Collectors (in situ) during the mixing period (average of $50 \%$ of hatched in situ ephippia). It is known that environmental conditions determine the timing of ephippia dormancy (Marcus et al., 1997, Cáceres and Tessier, 2003, Cáceres et al., 2007) and some authors suggest that the life history of the mother and risks experienced in the water column appear to influence ephippia dormancy (Marcus et al., 1997, Cáceres and Tessier, 2003). Considering the thermal stratification period as unfavourable for $D$. laevis, since this specie is found in low densities, the few ephippia produced remained in diapause as part of the egg bank. On the other hand, ephippia produced during the mixing period, when the environment seems to be more favourable, break dormancy in this same period, which explains the higher hatching rates. The hypothesis for it is that a high ephippia production could be a strategy for 
population genetics renewal (by sexual reproduction) and renewal of the dormant egg bank. During favourable conditions, some individuals emerge, multiply, produce new dormant eggs and die after that, renewing the stock of eggs in the sediment (Crispim and Watanabe, 2000; Panarelli et al., 2008). Although high population density was a stimulus for ephippia production (King and Snell, 1980; Ban, 1992) it seems not to have inhibited hatching. Higher ephippia hatching rates occurred concomitant with higher $D$. laevis densities in the water column. In addition, other factors may also have induced sexual reproduction during mixing period, such as predation and competition that were not considered in this study.

It is important to note that the hatching rates obtained by the Ephippial Collectors could still not be the real hatching rates because of three factors. First, we counted just the eggs that sank, neglecting the floating eggs (Cáceres et al., 2007; Pietrzak and Slusarczyk, 2006) which should be included in the total number of eggs produced. Second, it is known that females can produce unfertilised ephippia that should not be considered in the total of produced eggs, as the fertilised and unfertilised eggs are morphologically similar and it is very difficult to distinguish them. The fact that males were recorded in a very low frequency also contributes to the question: "do the ephippia really come from sexual reproduction?". The third possible bias is the re-suspension of eggs from the sediment to the water column, but, as we noted a good correspondence between the ephippial production and the active population in the water column, this seems to be of little influence.

Our methodology, despite its simplicity, was considered suitable for this type of study. The use of Ephippial Collectors was relatively more sensitive than corer samplings and made it possible to show seasonality in both laboratory and in situ hatching rates. Better estimations of hatching are a consequence of higher selectivity, since the Ephippial Collector excludes most ephippia produced at different periods, which is itself a cause of better estimations of ephippia production rates.

\section{Acknowledgements}

This work was supported by Conselho Nacional de Desenvolvimento Científico e Tecnológico (CNPq) and Fundação de Amparo a Pesquisa do Estado de Minas Gerais (FAPEMIG). We would like to thank the Instituto Estadual de Florestas de Minas Gerais (IEF) for the sampling permissions and the entire staff of the Brazilian Long-Term Ecological Research (LTER/UFMG site 4) coordinated by Prof. Dr. Francisco Barbosa, UFMG.

\section{References}

ALEKSEEV, V. and LAMPERT, W., 2001. Maternal control of resting-egg production in Daphnia. Nature, vol. 414, no. 6866, p. 899-901. http://dx.doi.org/10.1038/414899a. PMid:11780060

ALTERMATT, F. and EBERT, D., 2008. The influence of pool volume and summer desiccation on the production of the resting and dispersal stage in a Daphnia metapopulation. Oecologia, vol. 157 , no. 3, p. 441-452. http://dx.doi.org/10.1007/s00442-0081080-4. PMid:18597121

BAN, S., 1992. Seasonal distribution, abundance and viability of diapause eggs of Eurytemora affinis (Copepoda: Calanoida) in sediment of Lake Ohnuma, Hokkaido. Bulletin of the Plankton Society of Japan, vol. 39, p. 41-48.

BRANDÃO, LPM., FAJARDO, T., ESKINAZI-SANT'ANNA, E., BRITO, S. and MAIA-BARBOSA, P., 2012. Fluctuations of the population of Daphnia laevis Birge 1878: a six-year study in a tropical lake. Revista Brasileira de Biologia = Brazilian Journal of Biology, vol. 72, no. 3, p. 479-487. http://dx.doi.org/10.1590/ S1519-69842012000300010. PMid:22990818

BRENDONCK, L. and DE MEESTER, L., 2003. Egg banks in freshwater zooplakton: evolucionary and ecological archives in sediment. Hydrobiologia, vol. 491, no. 1-3, p. 65-84. http://dx.doi. org/10.1023/A:1024454905119

CÁCERES, CE. and SCHWALBACH, MS., 2001. How well do laboratory experiments explain field patterns of zooplankton emergence? Freshwater Biology, vol. 46, no. 9, p. 1179-1189. http://dx.doi.org/10.1046/j.1365-2427.2001.00737.x.

CÁCERES, CE. and TESSIER, AJ., 2004. To sink or swim: variable diapause strategies among Daphnia species. Limnology and Oceanography, vol. 49, no. 4, p. 1333-1340. http://dx.doi. org/10.4319/1o.2004.49.4_part_2.1333.

CÁCERES, CE. and TESSIER, AJ., 2003. How long to rest: the ecology of the optimal dormancy and environment constraint. Ecology, vol. 84, no. 5, p. 1189-1198. http://dx.doi.org/10.1890/00129658(2003)084[1189:HLTRTE]2.0.CO;2.

CÁCERES, CE., 1998. Interspecific variation in the abundance, production and emergence of Daphnia diapausing eggs. Ecology, vol. 79, no. 5, p. 1699-1710. http://dx.doi.org/10.1890/00129658(1998)079[1699:IVITAP]2.0.CO;2.

CÁCERES, CE., CHRISTOFF, AN. and BOEING, WJ., 2007. Variation in ephippial buoyancy in Daphnia pulicaria. Freshwater Biology, vol. 52, no. 2, p. 313-318. http://dx.doi.org/10.1111/j.13652427.2006.01695.x.

CRISPIM, MC. and WATANABE, T., 2000. Ovos de resistência de rotíferos presentes em sedimentos secos de um açude no semiárido paraibano. Acta Limnologica Brasiliensia, vol. 12, p. 89-94.

CRISPIM, MC., PAZ, RJ. and WATANABE, T., 2003. Comparison of different Moina minuta populations dynamics ecloded from dormant eggs in a semi-arid region in Brazil. Brazilian Journal of Ecology, vol. 5-6, p. 33-38.

DE STASIO, BT., 1989. The seed bank of a freshwater crustacean: copepodology for the plant ecologist. Ecology, vol. 70, no. 5, p. 1377-1389. http://dx.doi.org/10.2307/1938197.

DE STASIO, BT., 1990. The role of dormancy and emergence patterns in the dynamics of a freshwater zooplankton community. Limnology and Oceanography, vol. 35, no. 5, p. 1079-1090. http:// dx.doi.org/10.4319/1o.1990.35.5.1079.

GILBERT, JJ. and WILLIAMSON, CE., 1983. Sexual dimorphism in zooplankton (Copepoda, Cladocera and Rotifera). Annual Review of Ecology and Systematics, vol. 14, no. 1, p. 1-33. http:// dx.doi.org/10.1146/annurev.es.14.110183.000245.

GILBERT, JJ., 1995. Structure, development and induction of a new diapause stage in rotifers. Freshwater Biology, vol. 34, no. 2, p. 263-270. http://dx.doi.org/10.1111/j.1365-2427.1995.tb00886.x. 
GYLLSTRÖM, M. and HANSSON, LA., 2004. Dormancy in freshwater zooplankton: Induction, termination and the importance of benthic-pelagic coupling. Aquatic Sciences, vol. 66, no. 3, p. 274-295. http://dx.doi.org/10.1007/s00027-004-0712-y.

HAIRSTON JUNIOR, NG, 1996. Zooplankton egg banks as biotic reservoirs in changing environments. Limnology and Oceanography, vol. 41, no. 5, p. 1087-1092. http://dx.doi. org/10.4319/lo.1996.41.5.1087.

HAIRSTON JUNIOR, NG., HANSEN, AM. and SCHAFFNER, WR., 2000. The effect of diapauses emergence on the seasonal dynamics of a zooplankton assemblage. Freshwater Biology, vol. 45 , no. 2, p. 133-145.

HERZIG, A., 1985. Dormant eggs: a significant stage in the life cycle of crustaceans Leptodora kindti and Bythotrephes longimanus. Verhandlungen des Internationalen Verein Limnologie, vol. 22, p. 3088-3098.

IRIGOIEN, X., HARRIS, RP., VERHEYE, HM., JOLY, P., RUNGE, J., STARR, M., POND, D., CAMPBELL, R., SHREEVE, R., WARD, P., SMITH, AN., DAM, HG., PETERSON, W., TIRELLI, V., KOSKI, M., SMITH, T., HARBOUR, D. and DAVIDSON, R., 2002. Copepod hatching success in marine ecosystems with high diatom concentrations. Nature, vol. 419 , no. 6905 , p. $387-$ 389. http://dx.doi.org/10.1038/nature01055. PMid:12353032

JERSABEK, CD. and SCHABETSBERGER, R., 1995. Resting egg production and oviductal cycling in two sympatric species of alpine diaptomids (Copepoda:Calanoida) in relation to temperature and food availability. Journal of Plankton Research, vol. 17, no. 11, p. 2049-2078. http://dx.doi.org/10.1093/plankt/17.11.2049.

KERFOOT, WC., BUDD, JW., EADIE, BJ., VANDERPLOEG, HA. and AGY, M., 2004. Winter storms: Sequential sediment traps record Daphnia ephippial production, resuspension and sediment interactions. Limnology and Oceanography, vol. 49, no. 4, p. 1365-1381. http://dx.doi.org/10.4319/lo.2004.49.4 part 2.1365.

KING, C. and SNELL, T., 1980. Density-dependent sexual reproduction in natural populations of the rotifer Asplanchna girodi. Hydrobiologia, vol. 73, no. 1-3, p. 149-152. http://dx.doi. org/10.1007/BF00019440.

KLEIVEN, OT., LARSSON, P. and HOBAEK, A., 1992. Sexual reproduction in Daphnia magna requires three stimuli. Oikos, vol. 65, no. 2, p. 197-206. http://dx.doi.org/10.2307/3545010.

LUTZ, RV., MARCUS, NH. and CHANTON, JP., 1992. Effects of low oxygen concentrations on the hatching and viability of eggs of marine calanoid copepods. Marine Biology, vol. 114, no. 2, p. 241-247. http://dx.doi.org/10.1007/BF00349525

MARCUS, N., 1990. Calanoid copepod, cladoceran, and rotifer eggs in sea-bottom sediments of northern Californian coastal waters: identification, occurrence and hatching. Marine Biology, vol. 105, no. 3, p. 413-418. http://dx.doi.org/10.1007/BF01316312.

MARCUS, N., LUTZ, H. and CHANTON, J., 1997. Impact of anoxia and sulfite on the viability of eggs of three planktonic copepods. Marine Ecology Progress Series, vol. 146, p. 291-295. http://dx.doi.org/10.3354/meps146291.
MNATSAKANOVA, E. and POLISHCHUK, L., 1996. Role of parthenogenetic natality and emergence from diapausing eggs in the dynamics of some rotifer populations. Hydrobiologia, vol. 320, no. 1-3, p. 169-178. http://dx.doi.org/10.1007/BF00016818.

NIELSEN, DL., BROCK, MA., CROSSLE., HARRIS, K., HEALEY, M. and JAROSINSKI, I., 2003. The effect of salinity on aquatic plant germination and zooplankton hatching from two wetland sediments. Freshwater Biology, vol. 48, no. 12, p. 2214-2223. http://dx.doi.org/10.1046/j.1365-2427.2003.01146.x.

ONBÉ, T., 1978. Sugar flotation method for sorting the dormant eggs of marine cladocerans and copepods from sea bottom sediment. Bulletin of the Japanese Society for the Science of Fish, vol. 44, no. 10, p. 1141-1146. http://dx.doi.org/10.2331/suisan.44.1141.

PANARELLI, E.A., CASANOVA, SMC. and HENRY, R., 2008. The role of dormant eggs in the recovery of zooplankton community in a marginal lake of the Paranapanema River (São Paulo, Brazil), after a long drought period. Acta Limnologica Brasiliensia, vol. 20, p. 73-88.

PAUWELS, K., STOKS, R., VERBIEST, A. and DE MEESTER, L., 2007. Biochemical adaptation for dormancy in subitaneous and dormant eggs of Daphnia magna. Hydrobiologia, vol. 594, no. 1, p. 91-96. http://dx.doi.org/10.1007/s10750-007-9091-4.

PIETRZAK, B. and SLUSARCZYK. M., 2006. The fate of the ephippia-Daphnia dispersal in time and space. Polish Journal of Ecology, vol. 54, p. 709-714.

PIJANOWSKA, J. and STOLPE, G., 1996. Summer diapause in Daphnia as a reaction to the presence of fish. Journal of Plankton Research, vol. 18, no. 8, p. 1407-1412. http://dx.doi.org/10.1093/ plankt/18.8.1407.

R DEVELOPMENT CORE TEAM, 2010. $R$ : a language and environment for statistical computing. Vienna: R Foundation for Statistical Computing. Available from: $<$ http://www.R-project.org $>$.

SLOBODKIN, LB., 1954. Population dynamics in Daphnia obtusa. Kurz. Ecol. Monogr., vol. 24, no. 1, p. 69-88. http://dx.doi. org/10.2307/1943511.

SLUSARCZYK, M., 1995. Predator induced diapause in Daphnia. Ecology, vol. 76, no. 3, p. 1008-1013. http://dx.doi. org/10.2307/1939364.

TUNDISI, JG., 1997. Climate. In TUNDISI, JG. and SAIJO, Y. (Eds.). Limnological Studies on the Rio Doce Valley Lakes, Brazil. São Paulo: Brazilian Academy of Sciences. p. 7-11.

VANDEKERKHOVE, J., DECLERCK, S., BRENDONCK, L., CONDE-PORCUNA, JM., JEPPESEN, E. and DE MEESTER, L., 2005. Hatching of cladoceran resting eggs: temperature and photoperiod. Freshwater Biology, vol. 50, no. 1, p. 96-104. http:// dx.doi.org/10.1111/j.1365-2427.2004.01312.x.

WOLF, H. and CARVALHO, G., 1989. Resting eggs of lakeDaphania II. In situ observations on the hatching of eggs and their contribution to population and community structure. Freshwater Biology, vol. 22, no. 3, p. 471-478. http://dx.doi. org/10.1111/j.1365-2427.1989.tb01119.x. 